\title{
RESPON BEBERAPA GENOTIPE KEDELAI TERHADAP INFEKSI CPMMV (COWPEA MILD MOTTLE VIRUS)
}

\author{
Hasriadi Mat Akin ${ }^{1}$
}

\begin{abstract}
Response of various soybean genotipes against cowpea mild mottle virus (CPMMV) infection. The green house experiment was conducted to investigate the effect of CPMMV infection on growth and yield of various soybean varieties. Treatments were arranged in completely randomized block design in split plot experiment. Mainplots were virus-inoculated and uninoculated plants; subplots were eight soybean varieties: Wilis, Orba, MLG 2521, Taichung, B 3570, Dieng, Tidar, and Pangrango. The results of this experiment showed that CPMMV infection decreased vegetative growth and yield of soybean plant. The decrease of dry weigth of soybean plant proved that CPMMV infection inhibited the vegetative growth. Taichung variety susceptible to CPMMV was indicated by significant reduction of the growth and yield. B3570 line tolerance to CPMMV infection was proved by lower reduction of the yield.
\end{abstract}

Kata kunci: cowpea mild mottle virus, soybean

\section{PENDAHULUAN}

Kedelai adalah tanaman palawija terpenting dan merupakan sumber protein dan lemak nabati. Kandungan protein nabati dalam kedelai mencapai $35 \%$ bahkan pada beberapa varietas dapat mencapai 40-43\% . Di Indonesia kedelai dikonsumsi dalam bentuk olahan seperti tempe, tahu, tauco, dan kecap. Oleh sebab itu, kedelai merupakan sumber protein untuk masyarakat yang murah dan mudah mendapatkannya.

Permintaan kedelai di Indonesia jauh lebih besar dibandingkan dengan total produksi kedelai. Menurut Biro Pusat Statistik (1996) kebutuhan kedelai nasional mencapai 4,438 juta ton sedangkan produksi kedelai dalam negeri hanya 1,685 juta ton sehingga kekurangan sebesar 2,753 juta ton masih harus diimpor. Dengan demikian, berbagai usaha yang dapat dilakukan untuk meningkatkan produksi kedelai nasional akan membantu usaha mengurangi ketergantungan pada kedelai impor dan membantu menghemat devisa negara.

Produksi rata-rata per hektar kedelai di Indonesia masih rendah bila dibandingkan dengan produksi negara penghasil kedelai lainnya. Hasil ratarata per hektar baru mencapai 0,7 ton sedangkan di Brasil 1,5 ton dan USA 1,8 ton (Djauhari et al., 1982); selain itu produktivitas kedeleai di Indonesia sangat bervariasi dari 0,5-2,5 ton/ha (Sumarno, 1999). Usaha peningkatan produktivitas kedelai perlu dilakukan agar dapat memenuhi kebutuhan dalam negeri dan mengurangi impor. Di Indonesia, berbagai kendala yang menyebabkan rendahnya produktivitas kedelai antara lain kendala biologis, yaitu insiden dan intensitas serangan penyakit di lapangan.

Kendala biologi sebagai akibat epidemi penyakit masih tetap menjadi kendala utama dalam produksi kedelai meskipun kendala lainnya telah dapat diatasi. Kondisi di Indonesia yang beriklim tropis dalam hal tertentu memberikan kondisi yang kondusif untuk perkembangan dan penyebaran patogen di lapangan. Kondisi daerah tropika menguntungkan perkembangan serangga vektor penyebar patogen. Tidak adanya musim dingin yang dapat mematahkan siklus hidup patogen dan menekan keberadaan serangga vektor di lapangan menyebabkan patogen dan serangga vektor menjadi selalu tersedia dan terakumulasi tingkat populasinya dari tahun ke tahun. Selain itu, pola tanam yang cenderung mengarah pada pola tanam monokultur menyebabkan permasalahan serangan penyakit menjadi lebih parah.

Penyakit virus pada tanaman kedelai yang disebabkan oleh CPMMV merupakan salah satu penyakit endemi pada pertanaman kedelai di Indonesia dan merupakan salah satu penyebab rendahnya hasil kedelai (Saleh \& Sumarno, 1993). Hasil pengamatan menunjukkan bahwa CPMMV merupakan virus yang endemik pada areal-areal pertanaman kedelai di pulau Jawa dan Sumatran (Jumanto et al., 1999; Roechan, 1992). Oleh sebab itu, penelitian untuk mendapat varietas unggul yang tahan terhadap CPMMV perlu dilakukan mengatasi epidemi CPMMV (cowpea mild mottle virus) pada budidaya kedelai. Penelitian pada tahap ini bertujuan untuk mengetahui respon beberapa genotipe kedelai yang

\footnotetext{
${ }^{1}$ Dosen Jurusan Proteksi Tanaman, Fakultas Pertanian Universitas Lampung
} 
diharapkan sebagai sumber gen ketahanan terhadap CPMMV.

\section{METODE PENELITIAN}

Penelitian dilaksanakan di rumah kaca dan Laboratorium Mikologi dan Virologi Tumbuhan Jurusan Proteksi Tanaman Fakultas Pertanian Universitas Lampung. Penelitian ini dilakukan pada bulan Februari 2000 sampai Mei 2001.

Perlakuan disusun dalam petak terbagi dengan Rancangan Acak Kelompok (RAK). Petak utama terdiri atas kontrol atau tanaman yang tidak diinokulasi $\left(\mathrm{I}_{0}\right)$ dan tanaman yang inokulasi CPMMV $\left(\mathrm{I}_{1}\right)$; anak petak terdiri atas genotipe 8 varietas kedelai $\left(\mathrm{V}_{1}\right.$ : Wilis, $\mathrm{V}_{2}$ : Orba, $\mathrm{V}_{3}$ : MLG 2521, $\mathrm{V}_{4}$ : Taichung, $\mathrm{V}_{5}$ : B 3570, $\mathrm{V}_{6}$ : Dieng, $\mathrm{V}_{7}$ : Tidar dan $\mathrm{V}_{8}$ : Pangrango). Peubah yang diamati adalah bobot berangkasan kering tanaman, bobot kering biji, dan persentase biji yang tidak normal. Data hasil pengamatan dianalisis dengan sidik ragam dan perbandingan nilai tengah menggunakan uji beda nyata jujur (BNJ) pada taraf $5 \%$.

Kedelai ditanam dalam polibeg ukuran $10 \mathrm{~kg}$ sedalam 2-3 cm, yang diisi dengan media tumbuh berupa campuran tanah, pasir, dan pupuk kandang dengan perbandingan 2:1:1. Tanaman dipelihara dalam rumah kaca kedap serangga. Inokulasi CPMMV dilakukan secara mekanik pada tanaman berumur 10 hari setalah tanaman (hst). Inokulum adalah sap tanaman daun kedelai terinfeksi CPMMV yang digerus dalam buffer posfat $\mathrm{pH} 7$ dengan perbandingan $1 / 9(\mathrm{w} / \mathrm{v})$.

\section{HASIL DAN PEMBAHASAN}

Infeksi CPMMV pada tanaman kedelai menimbulkan gejala sistemik berupa gejala mosaik, pengurangan pertumbuhan vegetatif, dan generatif tanaman. Pengurangan pertumbuhan vegetatif ditunjukkan oleh pengurangan bobot berangkasan kering tanaman. Sedangkan pengurangan pertumbuhan generatif ditunjukkan oleh penurunan bobot biji kering dan persentase biji yang tidak normal. Hasil penelitian juga menunjukkan bahwa serangan CPMMV menurunkan bobot berangkasan kering tanaman antara 15,5-53,4\% (Tabel 1). Varietas Taichung merupakan varietas yang bobot berangkasan keringnya paling rendah dan diikuti dengan persentase penurunan bobot berangkasan kering yang tinggi yaitu 53,4\%. Penurunan bobot berangkasan kering merupakan akibat dari pengaruh infeksi CPMMV pada daun yang bergejala mosaik. Penampakan gejala mosaik terjadi akibat adanya kelainan sitologi berupa tidak normalnya kloroplas sebagai organel yang berfungsi dalam fotosistesis dan sintesis sukrosa. Infeksi sistemik virus secara umum akan mengurangi total klorofil dan malformasi bentuk kloroplas akan mengurangi efisiensi fotosintesis tanaman (Goodman et al., 1986).

Tabel 1. Bobot berangkasan kering tanaman kedelai

\begin{tabular}{lccc}
\hline Varietas & Tanaman tidak diinokulasi (gr) & Tanaman terinfeksi (gr) & Penurunan (\%) \\
\hline Wilis & $19,0 \mathrm{c}$ & $14,6 \mathrm{~b}$ & 23,4 \\
Orba & $14,5 \mathrm{e}$ & $9,5 \mathrm{e}$ & 34,6 \\
MLG2521 & $20,9 \mathrm{~b}$ & $14,6 \mathrm{~b}$ & 30,0 \\
Taichung & $7,7 \mathrm{f}$ & $3,6 \mathrm{f}$ & 53,4 \\
B3570 & $24,3 \mathrm{a}$ & $15,9 \mathrm{~b}$ & 34,7 \\
Dieng & $15,8 \mathrm{~d}$ & $13,4 \mathrm{c}$ & 15,5 \\
Tidar & $16,2 \mathrm{~d}$ & $11,3 \mathrm{~d}$ & 30,2 \\
Pangrango & $25,6 \mathrm{a}$ & $17,2 \mathrm{a}$ & 33,0 \\
\hline
\end{tabular}

Keterangan: Angka dalam kolom yang diikuti huruf yang berbeda menunjukkan berbeda nyata menurut uji BNJ $(\alpha=5 \%)$ 
Tabel 2. Bobot biji kering dan persentase biji tidak normal

\begin{tabular}{lcccc}
\hline Varietas & $\begin{array}{c}\text { Tanaman tidak } \\
\text { diinokulasi } \\
\text { (gr) }\end{array}$ & $\begin{array}{c}\text { Tanaman } \\
\text { terinfeksi (gr) }\end{array}$ & $\begin{array}{c}\text { Penurunan } \\
\mathbf{( \% )}\end{array}$ & $\begin{array}{c}\text { Biji tidak normal } \\
(\%)\end{array}$ \\
\hline Wilis & $32,1 \mathrm{a}$ & $15,5 \mathrm{ab}$ & 51,6 & $9,0 \mathrm{c}$ \\
Orba & $22,9 \mathrm{~d}$ & $15,9 \mathrm{a}$ & 30,5 & $27,4 \mathrm{~b}$ \\
MLG2521 & $19,3 \mathrm{c}$ & $15,4 \mathrm{ab}$ & 20,2 & $8,3 \mathrm{c}$ \\
Taichung & $14,3 \mathrm{~g}$ & $7,8 \mathrm{~d}$ & 45,6 & $54,2 \mathrm{a}$ \\
B3570 & $16,1 \mathrm{f}$ & $14,2 \mathrm{~b}$ & 11,5 & $7,6 \mathrm{c}$ \\
Dieng & $20,8 \mathrm{c}$ & $11,5 \mathrm{c}$ & 44,6 & $3,9 \mathrm{~cd}$ \\
Tidar & $23,8 \mathrm{~b}$ & $16,0 \mathrm{a}$ & 32,9 & $26,8 \mathrm{~b}$ \\
Pangrango & $18,5 \mathrm{e}$ & $11,4 \mathrm{c}$ & 38,3 & $32,9 \mathrm{~b}$ \\
\hline
\end{tabular}

Keterangan: Angka dalam kolom yang diikuti huruf yang berbeda menunjukkan berbeda nyata menurut uji BNJ $(\alpha=5 \%)$

Hasil penelitian ini juga menunjukkan bahwa infeksi CPMMV secara nyata menurunkan bobot biji, dan persentase biji kedelai yang tidak normal (Tabel 2). Varietas Taichung yang mengalami hambatan pertumbuhan tertinggi menghasilkan bobot biji yang paling rendah dan persentase penurunan bobot biji yang tinggi. Hal itu menunjukkan bahwa varietas Taichung memberikan respon suseptibel terhadap infeksi CPMMV. Sebaliknya galur B3570 memberikan reaksi toleran terhadap infeksi CPMMV yang ditunjukkan oleh persentase penurunan bobot biji yang relatif lebih rendah yaitu $11,5 \%$ walaupun hambatan pertumbuhan vegetatifnya mencapai $34,7 \%$.

\section{SIMPULAN}

Dari penelitian rumah kaca ini dapat disimpulkan bahwa terdapat perbedaan respon masing-masing genotipe kedelai terhadap CPMMV. Respon pengurangan pertumbuhan vegetatif dan generatif tertinggi ditunjukkan oleh varietas Taichung. Serangan CPMMV dapat menurukan kualitas dan kuantitas biji kedelai. Penurunan kuantitas hasil kedelai ditunjukkan oleh penurunan bobot biji antara 11,5-53,6\%, sedangkan penurunan kualitas hasil ditunjukkan oleh persentase biji tidak normal antara $7,6-54,35 \%$.

\section{DAFTAR PUSTAKA}

BPS, 1996. Luas panen, produksi dan hasil perhektar tanaman pangan. Dalam: Statistik Indonesia. Biro Pusat Statistik. Jakarta.
Djauhari, A., Subandi, S. Arifin, Sumarno, \& S. Somaatmadja. 1982. Palawija Crops in Indonesia. Country Report on Course Grains and Legumes. Cen. Res. Inst. For Food Crops, Bogor.

Goodman, R.N, Z. Kiraly, \& K.R. Wood. 1986. The Biochemistry and Physiology of Plant Disease. University of Missouri Press, Columbia.

Jumanto, H., M. Roechan, M. Muhsin, Asadi, M. Nakano, \& H. Sawahata. 1999. Distribution of soybean virus diseases in Indonesia. Risearch Institute for Food Crop Biotechnology, Bogor.

Sumarno. 1999. Prospect of soybean development in Indonesia. In: Sumarno, S. Asanuma, W.A.Adil (eds). Soybean Breeding for Virus Resistance and Rhizobium Utilization. Central Reseach Institute for Food Crops.

Roechan, M. 1992. Virus-virus pada kedelai (Glycine max) di Jawa dan Lampung: Identifikasi dan kemungkinan pengendaliannya (tidak dipublikasikan). Disertasi Doktor. Universitas Padjadjaran, Bandung.

Saleh, N. \& Sumarno. 1993. Soybean in Asia. N. Chomchalow \& P. Laosuwan (eds.). Science Publishers. 